\title{
Role of Kalmegha (Andrographis paniculata (Burm.F.) Wall. Ex Nees) in treating Vatarakta (Gout)
}

\author{
Dr. Harsh Sehgal ${ }^{* 1}$, Dr. Bhavna Singh ${ }^{2}$ and Dr. Sanandan Thapliyal ${ }^{3}$ \\ 1PG Scholar, PG Department of Dravya Guna Uttaranchal Ayurvedic College, Dehradun, Uttarakhand, India \\ 2Prof. and HOD, PG Department of Dravya Guna Uttaranchal Ayurvedic College, Dehradun, Uttarakhand, India \\ ${ }^{3}$ Associate Prof., Department of Kaya Chikitsa, Uttaranchal Ayurvedic College, Dehradun, Uttarakhand, India
}

\begin{abstract}
Andrographis paniculata (Burm.f.) Wall. Ex. Nees (A. Paniculata), i.e. Kalmegha is a medicinal plant traditionally used for various diseases such as fever, diarrhea, worm infestation, hepatic and skin diseases. Modern studies have also explicitly revealed that $A$. Paniculata has a wide range of pharmacological effects such as anti-inflammatory, anti-hyperglycemic, anti-diarrhoeal, anti-viral, anti-malarial, hepato-protective, anti-cancer, anti-human immunodeficiency virus (HIV), and also work as an immune stimulator. On the other hand, Gout (Vatarakta) is one common metabolic disorder which affects over $1 \%$ of the world's adult population. Objective: To assess the clinical efficacy of A. Paniculata in Gouty Arthritis.

Study Design: A clinical research, prospective in style, wherein a hypothesis, based on the previous studies on the various effects of A. Paniculata, was made; to assess its efficacy in treating Gout.

Methodology: Randomly selected patients ( $\mathrm{n}=31$ ) were administered powder of A. Paniculata, 2 gms thrice daily with water, for 45 days with a follow-up in every 15 days for one month. Assessment of the treatment was based on before treatment (BT) and after treatment (AT) effects of A. Paniculata on the parameters namely; subjective, i.e. the symptoms of Gout and objective, i.e. the levels of Serum Uric Acid.

Results: In subjective parameters, Wilcoxon non-parametric test was used. The outcome shows that except the symptom i.e. Pallor (shwetata), in all other symptoms of Gout, p value was either $<0.05$ or $<0.01$, which is considered to be significant to highly significant. In objective parameter, $\mathrm{Z}$ test was used, in which the outcome of $\mathrm{p}$ value was $<0.01$, which indicates that the effect of $A$. Paniculata on Serum Uric Acid is highly significant.
\end{abstract}

Keywords: Kalmegha, Andrographis paniculata, Gout, Vatarakta, Serum Uric Acid, Clinical Studies

Article Info: Received 29 Sep, 2018; Review Completed 29 Oct 2018; Accepted 30 Oct 2018; Available online 15 Nov 2018

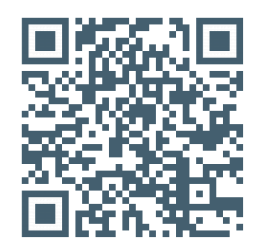

\section{Cite this article as:}

Sehgal H, Singh B, Thapliyal S, Role of Kalmegha (Andrographis paniculata (Burm. F.) Wall. Ex Nees) in treating Vatarakta (Gout), Journal of Drug Delivery and Therapeutics. 2018; 8(6):98-101 DOI: http://dx.doi.org/10.22270/jddt.v8i6.2024

Harsh Sehgal, PG Scholar, Department of Dravya Guna, Uttaranchal Ayurvedic College, Dehradun, Uttarakhand, India

\section{INTRODUCTION}

With an increase in the erratic ways of dietary and life-style habits, we are witnessing an ever growing menace of several metabolic disorders. Gouty arthritis is one of them affecting over $1 \%$ of the world's adult population. ${ }^{1}$ Modern aspect defines gout as a hereditary metabolic disease that is a form of acute arthritis and is marked by inflammation of the joints with the etiology of excessive uric acid in the blood (hyperuricemia) and deposits of urates of sodium in and around joints. Several different metabolic abnormalities may also cause hyperuricemia. ${ }^{2}$

Gout is a disease of antiquity. Considering the symptoms and pathogenesis, Gout can be co-related with Vatarakta in Ayurvedic sciences. Some common symptoms of Vatarakta include; Kandu (Itching), Daha (Burning sensation), Ruja
(Pain), Sira-ayama (Dilatation of the vessels), Toda (Pricking pain), Sphurana (Trembling or throbbing sensation), Sira-akunchana (Contraction), Shyav-twak (Cyanosis of skin), Rakta-twak (Reddish coloration of skin), Bheda (Splitting type of pain), Gourava (Heaviness), Suptata (Numbness), etc. ${ }^{3}$

Modern Drugs used to treat acute attacks and prevent future attacks of Gout includes: Non-steroidal antiinflammatory drugs (NSAIDs), Colchicine and Corticosteroids, etc. Owing to the rise in awareness about the disease, its treatments and undesirable possible adverse effects of modern drugs, more and more people are opting for a safe and cost effective treatment options. In the past few years, there is growing an interest in Ayurveda, especially in the herbal sector, worldwide. 
Kalmegha (Andrographis paniculata (Burm.f.) Wall.ex Nees), Family - Acanthaceae, a common herb, used extensively in liver disorders and is a potent blood purifier is found throughout the planes of India, Pakistan, Sri Lanka and West Indies. ${ }^{4}$

Kalmegha is commonly known as Bhunimba, Yavatikta and Desi chirayata. According to Ayurvedic texts, Kalmegha is a herb with Tikta rasa, Katu vipaka, Laghu-Ruksha Guna, and Ushna Veerya and due to these attributes it performs various therapeutical actions such as Vishodhan (purificatory), Tridosha-shaman (helps balancing Tridoshas), Shothaghna (edema) and Udar-Rog Nashak (gastro-intestinal disorders) ${ }^{5}$, Kapha-Pitta shamana (pacifies Kapha-Pitta), Deepan (appetizer), Swedan (diaphoretic), Jwaraghna (anti-pyretic), Kriminashak (antihelminthic) and Kushthaghna (skin diseases) ${ }^{7}$. It is a very effective Katu-paushtik (bitter yet nourishing), and Yakritrog Nashak (hepatoprotective) drug. ${ }^{6}$ Modern studies have also explicitly revealed that A.Paniculata has a wide range of pharmacological effects and some of them extremely beneficial such as anti-hyperglycemic (Bu-Chin et al., 2003) 8, anti-diarrhoeal (Gupta et al.,1990; Gupta et al.,1993) 9,10, anti-viral (Wiart et al., 2005) 11, anti-malarial (Mishra et al.,1992) ${ }^{12}$, hepato-protective (Clander et al., 1995) ${ }^{13}$, anticancer (Cheung et al., 2005) 14, anti-human immunodeficiency virus (HIV) (Calabrese et al., 2000) 15 , and also work as an immune stimulator (Puri et al., 1993) 16 .

\section{MATERIAL AND METHODS}

A clinical study, made to observe the effect of Kalmegha ( $A$. paniculata) in Vatarakta (Gout), was approved by the Research Development Committee (RDC) of Uttarakhand Ayurved University, Harrawala, Dehradun on July 28th, 2016.

\section{1) Source of the drug:}

The plant material, A. Paniculata, whole plant, used in the clinical study was procured from a reliable source of Dehradun market. Its authentication was done in the PG Department, DravyaGuna, UAC, Dehradun.

\section{2) Identity, Purity and Strength:}

At the same time, the whole plant of A.Paniculata was collected from the Non Wood Forest Products (NWFP) Division, Forest Research Institute (FRI), Dehradun and a herbarium specimen was made and deposited at the Systematic Botany Branch (SBB), FRI, Dehradun. The plant was authenticated and an Herb Registration Number 172435, dated November 17th, 2017 was assigned to it. This plant sample was set as standard.

Thin layer chromatography (TLC) technique was used to ascertain the identity and quality of the commercially available plant material through comparison of its TLC profile with that of the authenticated plant material used as standard. Results of the comparative TLC revealed that both the samples were qualitatively alike.

3) Preparation of drug for the clinical trial: A total of 15 kgs of commercially available plant material of A.Paniculata was purchased and after cleaning, washing and shade drying, it was milled and a fine powder of 35 mesh size from a normal sieve was prepared.

4) Dosage and Duration of treatment: Dosage of 2 gms of A.Paniculata powder thrice daily to be taken with water was prescribed.
5) Number of patients: Total 43 patients were registered for the studies from the OPD of Uttaranchal Ayurvedic Hospital, Dehradun during the month of August 2017.

6) Follow-up: After the completion of 45 days treatment, a follow-up was done for one month in every 15 days to ascertain the adverse effects of the treatment if any. Out of 43 cases registered for the study, 31 cases turned up for full follow-ups.

\section{7) Inclusion Criteria:}

- Randomly selected patients within the age group of 20-60 years irrespective of sex, cast, religion, economic status.

- Patients having common clinical features of Vatarakta as described in Ayurveda, namely; oedema (shvyathu), stiffness (stabdhata), inflammation (shotha), itching (kandu), heaviness (guruta), numbness (suptata) and piercing pain (toda) in knees, shanks, thighs, waist, shoulder, hands, feet and joints of the body. And fatigue (shram), pallor (shwetata), thirst (trishna) and indigestion (ajirna).

- $\quad$ Diagnosed patient of Vatrakta (Gout).

- Patients having serum uric acid level 5.5 to 10.0 $\mathrm{mg} / \mathrm{dl}$.

\section{8) Exclusion Criteria:}

- Patients with Chronic Debilitating Diseases.

- Patients having Cardio Vascular Disease.

- Patients below 20 years and above 60 years.

- Patients suffering from any Infectious Disease.

- Diagnosed cases of Thyroid abnormalities.

- Patients of CRF and Hepatic disorders.

- Immuno-compromised patients.

- Patients of Gout associated with any severe arthritis condition like acute rheumatoid arthritis, crooked fingers (anguli-vakrata), mental confusion (moha) and tumor like hard swelling (arbud) will be excluded from the study.

9) Assessment Criteria: The assessment criteria of the clinical studies were both subjective and objective.

a) Subjective (symptoms based):

- Oedema (shvyathu)

- Stiffness (stabdhata)

- Inflammation (shotha)

- Itching (kandu)

- Heaviness (guruta)

- Numbness (suptata)

- $\quad$ Piercing pain (toda)

- $\quad$ Fatigue (shram)

- Pallor (shwetata)

- $\quad$ Thirst (trishna)

- Indigestion (ajirna)

\section{b) Objective:}

\section{- $\quad$ Serum Uric Acid}

10) Pathyapathya (diet and life-style guidelines): Pathya and Apathya in terms of diet and life-style guidelines were prescribed as mentioned in Ayurvedic texts.

- Do's (Pathya Aahar-Vihaar): Light and easy to digest food, barley (puranyava), wheat (godhuma), shali rice, flesh broth of gallinaceous birds (vishikar mansras), pigeon pea (arhardaal), bathua, bengal gram (chana), 
petha, moongdaal, red lentil (masoordaal), bitter gourd (karela), pointed gourd (parwal), amla, raisins (munakka and kishmish), black night-shade (makoya), milk and pure ghee. Oil massages (abhyanga), poultice (upnaha), pradeha and parishek.

- Don'ts (Apathya Aahar-Vihaar): Katu rasa (pungent), food which causes heating effect and is heavy to digest, fried, spicy, sour (amla) and salty (lavan) food items, curd and its products, sesame (til) and its products, black gram (udad), horse gram (kulath), alcohol, beans (sem) and radish. Diurnal sleep (diwaswap), sun bathing (aatap-sewan), excessive exercise and over indulgence in sexual activities. a) Subjective (symptoms based): Wilcoxon nonparametric test was used to analyze the effect of A.Paniculata on the various symptoms of Vatarakta (Gout) in different patients under study. The positive and negative ranks based upon the patient's response along with the Wilcoxon statistics are shown in the Table 1 . The p-value mentioned in this table is for two tailed test and at $5 \%$ level of significance. The meaning of nature of the rank is as:

Negative Ranks - Grade is decreasing i.e. improvement in the symptom after treatment.

Positive Ranks - Grade is increasing i.e. deterioration in the symptom after treatment.

Ties - No difference in the grades i.e. no change or relief in the symptom after treatment.

The results were analyzed by the Statistical software SPSS (version 16).

\section{OBSERVATIONS AND RESULTS}

Table 1: Ranks Due to Wilcoxon Non parametric test

\begin{tabular}{|l|c|c|c|c|c|c|}
\hline \multirow{2}{*}{ Symptom } & \multicolumn{3}{|c|}{ Ranks } & \multirow{2}{*}{ \% Improvement } & Wilcoxon Statistic & p value \\
\cline { 2 - 4 } & Negative & Positive & Ties & & & \\
\hline Edema & 15 & 0 & 16 & $48.35 \%$ & -3.771 & $<0.01$ \\
\hline Stiffness & 21 & 0 & 10 & $67.74 \%$ & -4.491 & $<0.01$ \\
\hline Inflammation & 9 & 0 & 22 & $29.03 \%$ & -3.000 & $<0.01$ \\
\hline Itching & 4 & 0 & 27 & $12.90 \%$ & -2.000 & $<0.05$ \\
\hline Heaviness & 13 & 0 & 18 & $41.94 \%$ & -3.606 & $<0.01$ \\
\hline Numbness & 6 & 0 & 25 & $19.35 \%$ & -2.449 & $<0.05$ \\
\hline Piercing pain & 26 & 0 & 5 & $83.87 \%$ & -4.874 & $<0.01$ \\
\hline Fatigue & 7 & 0 & 24 & $22.58 \%$ & -2.646 & $<0.01$ \\
\hline Pallor & 0 & 0 & 31 & $0 \%$ & 0.000 & $>0.05$ \\
\hline Thirst & 5 & 0 & 26 & $16.13 \%$ & -2.236 & $<0.05$ \\
\hline Indigestion & 22 & 0 & 9 & $70.97 \%$ & -4.690 & $<0.01$ \\
\hline
\end{tabular}

The outcome in the above table indicates that out of 11 symptoms assessed, in 7 symptoms namely, edema (shvyathu), stiffness (stabdhata), inflammation (shotha), heaviness (guruta), piercing pain (toda), fatigue (shram), and indigestion (ajirna), p value obtained was less than < 0.01 which is considered to be highly significant at $5 \%$ level of significance. In 3 symptoms namely, itching (kandu), numbness (suptata) and thirst (trishna), $\mathrm{p}$ value was found to be less than $<0.05$ which is considered to be significant at $5 \%$ level of significance. It was only the symptom pallor (shwetata) which showed the $\mathrm{p}$ value $>0.05$, which means that A.Paniculata shows no effect on pallor (shwetata) symptom of Vatarakta (Gout).

b) Objective: $Z$ Test was used to see the significant effect, if any, of A. Paniculata on the levels of Serum Uric Acid based upon 31 observations under study.

Table 2: Effect on BT and AT of Kalmegha (A. Paniculata) on Uric Acid: Descriptive Statistics and paired Z test for significance

\begin{tabular}{|l|l|l|l|l|l|}
\hline Treatment & Mean ( \pm SEM) & $\begin{array}{l}\text { Correlation } \\
\text { (p alue) }\end{array}$ & $\begin{array}{l}\text { Mean Difference } \\
(\text { SD })\end{array}$ & $\begin{array}{l}\text { 95\% Confidence } \\
\text { Interval }\end{array}$ & p value \\
\hline BT & $6.73( \pm 0.11)$ & $0.713(<0.01)$ & $0.655(0.445)$ & $0.492-0.818$ & $<0.01$ \\
\hline AT & $6.07( \pm 0.10)$ & & & & \\
\hline
\end{tabular}

Above table shows that the average values of Serum Uric Acid for BT is $6.73 \pm 0.110$ (mean \pm SEM) and the same is $6.07 \pm 0.10$ for the AT. The sample correlation coefficient between BT and AT is found to be 0.713 which is highly significant at $1 \%$ level of significance as $p$ value is less than 0.01 . In addition, mean difference of Uric Acid was 0.655 $\mathrm{mg} / \mathrm{dl}$. The lower and upper bounds of this difference were found to be $0.492 \mathrm{mg} / \mathrm{dl}$ and $0.818 \mathrm{mg} / \mathrm{dl}$ respectively.

It shows that there is a significant difference between BT and AT of A. paniculata on Serum Uric Acid.

\section{DISCUSSION}

In both subjective and objective parameters, as mentioned above, a significant difference was found between BT and AT of using A. Paniculata. There is a marked improvement in the symptom indigestion (ajirna) shown by $70.97 \%$ of the patients. It could be because of the Tikta Rasa, Laghu Guna and Katu Vipaka of A. Paniculata, all of which acts as laghav karma in the body. Appetite, flatulence, acidity and bowel movements becomes better, which further leads to the improvement of other symptoms such as heaviness (guruta) and fatigue (shram). This once again proves the efficacy of $A$. paniculata on the proper functioning of liver enzymes. And the synonym "Udarnashini" of Dhanwantari Nighantu [5] is justified. $67.74 \%$ of the patients showed improvement in the stiffness (stabdhata), while $29.03 \%$ of 
the patients got significant results in inflammation (shotha). This could be because of the Kapha pitta shamaka action of A. paniculata. Edema (shvyathu) also gets improved in $48.35 \%$ of the patients because of the Ruksha property and Ushna Veerya of A. paniculata.

It is interesting to note that except for one patient, the Serum Uric Acid levels of the remaining 30 patients showed good improvement. This fact again confirms the already established blood purifying properties of $A$. Paniculata. And hence piercing pain (toda), which was present in every patient, got highly significant results with $83.87 \%$ of patients reported to have marked improvement.

Couple of patients (age > 55 years) gave no response in any of the subjective and objective parameters. It could be because of their already sluggish metabolism, due to chronicity and age factor. However, many patients in this age bracket responded well with the recent symptoms of pain in smaller joints.

There were no adverse or undesirable side effects noted, in terms of clinical presentation or lab investigation, post studies. It is important to note that Pathya-Apathya plays

\section{REFERENCES}

1. Ariev A.L., Kunitskaya N.A. \& Kozina L.S. Adv Gerontol 2013; 3: 138. https://doi.org/10.1134/S2079057013020021.

2. Clayton L. Thomas (Editor), Taber's Cyclopedic Medical Dictionary, 16th Edition, F.A.Davis Company, Page - 756.

3. Tripathi B, Charaka Samhita of Agnivesh, Elaborated by Charaka and Dridhbala, Volume - II, with Charaka-Chandrika Hindi commentary, Fourth edition 1996, Chaukhambha Subharati Prakashan, Varanasi, Chikitsasthan, 29/20.

4. Kulyal P., Tiwari U.K., Shukla A. and Gaur A.K. Chemical constituents isolated from Andrographis paniculata. Ind. J. Chem., 2010; 49B:356-359.

5. Dr. Jharkhandey Ojha, Ph.D and Dr.Umapati Mishra, MD (Ayu.) Dhanwantari Nighantu, Chaukhambha Subharati Prakashan, Varanasi, Guduchyadi Prathamo Varga, Shloka - 257.

6. Bapalal G. Vaidya, Nighantu Adarsh, Chaukhambha Bharati Academy, Varanasi, Vasadi Varga, Page - 229.

7. Prof. Priya Vrat Sharma, Priya Nighantu, Chaukhambha Surbharti Prakashan, Varanasi, Shatpushpadi Varga, Shloka 135-136.

8. Bu-Chin Y., Chen-Road H., Wang-Chuan C. and Juei-Tang C. Antihyperglycemic effect of andrographolide in streptozotocin- induced diabetic rats. Planta Med., 2003; 69:1075-1079.

9. Gupta S., Choudhry M. A., Yadava J. N. S., Srivastava V. and Tandon J.S. Antidiarrhoeal activity of diterpenes of Andrographis paniculata (Kal-Megh) against Escherichia col enterotoxine in in vivo models. Int. J. Crude Drug Res., 1990; 28:273-283. an important role in curing the disease. The patients, who followed the prescribed diet and life-style guidelines diligently, responded well and took less time to recover.

There were some other notable benefits too. One patient in the study was suffering from pitting nails, reported to have complete relief in this condition, after 45 days of the treatment. Another patient of psoriasis reported regression in the symptoms of psoriasis as well.

\section{CONCLUSION}

The present study illustrates that the overall effect of A.paniculata, with its Rasa, Guna, Veerya, Vipaka and Karma, corrects the metabolism and purifies the blood, eventually helping in disintegrating the pathogenesis (samprapti-vighatan) of Vatarakta (Gout). A. paniculata, is a potent medicinal plant with high adaptive qualities. With its varied usage in Kushta, Kandu, Shvyathu, Yakratroga, Krimi, Kushta, Jwara, etc, and with the highly encouraging results on Vatarakta as illustrated in the present study, it's one of the synonym i.e. Yashaskari - means that brings Yash (success and fame) to the physician is well established.
10. Gupta S., Yadava J. N. S. and Tandon J. S. Antisecretory (antidiarrhoel) activity of Indian medicinal plants against Escherichia Coli enterotoxin-induced secretion in rabbit and guinea pig ileal loop models. Pharm. Biol., 1993; 31:198-204.

11. Wiart C., Kumar K., Yusof M. Y., Hamimah H., Fauzi Z. M. and Sulaiman M. Antiviral properties of ent-labdene diterpenes from Andrographis paniculata Nees, inhibitors of herpes simplex virus type 1. Phytother. Res., 2005; 19:1069-1070.

12. Mishra P., Pal N. L., Guru P. Y., Katiyar J. C., Srivastava V. and Tandon J. S. Anti-malarial activity of Andrographis paniculata (Kalmegh) against Plasmodium berghei NK65 in Mastomys natalensis. Int. J. Pharmacogn., 1992; 30:263-274.

13. Clander R., Srivastava V., Tandon J. and Kapoor N.K. Antihepatotoxic activity of diterpenes of Andrographis paniculata (Kal-Megh) against Plasmodium berghei induced hepatic damage in Mastomys natalensis. Int. J. Pharmacogn., 1995; 33:135-138.

14. Cheung H. Y., Cheung S. H., Li J., Cheung C. S., Lai W. P., Fong W. F. and Leung F. M. Andrographolide isolated from Andrographis paniculata induces cell cycle arrest and mitochondrialmediated apoptosis in human leukemic HL-60 cells. Planta Med., 2005; 71:1106-1111.

15. Calabrese C., Berman S. H., Babish J. G., Ma X., Shinto L., Dorr M, Wells K., Wenner C.A. and Standish L.J. A phase I trial of andrographolide in HIV positive patients and normal volunteers. Phytoether. Res., 2000; 14:333-338.

16. Puri A., Saxena R., Saxena R. P., Saxena K. C., Srivastava V. and Tandon J. S. Immunostimulant agents from Andrographis paniculata. J. Nat. Prod., 1993; 56:995-999. 